\title{
技術報告
}

\author{
温度制御型サーミスター真空䛨 \\ 堀 越 源 一* \\ （昭和 37 年 10 月 6 日受理）
}

\section{A Thermistor Gauge of Temperature Controled Type}

\section{Genichi HORIKOSHI}

(The Institute for Nuclear Study, Univ. of Tokyo, Tanashimachi, Tokyo)

A new type thermistor vacuum gauge is described. In a thermistor, the electric resistance changes largely with its temperature, so that it can be used as a pressure sensitive elenent in a thermal vacuum gauge. Owing to a nonlinear relation between the temperature and electric resistance in a thermistor, however, the problem of the ambient temperature compensation in a thermistor gauge is very difficult. So a gauge of new type was designed, emploging two thermistors one of which is a monitor of gauge head temperature. The signal from the temperature monitoring thermistor drives a vacuum tube and control its plate current, the load of which is a nichrome wire winding around the gauge head. If the temperature of the gauge head is lower than the setting point, the plate current increases so that the temperature will be raised and vice versa, thus the gauge head is hold at a constant temperature irrespective of the ambient temperature. Some theoretical discussions concerning thermal vacuum gauge designs are presented. The measureable pressure range is 10 torr to $10^{-3}$ torr. Thermistor gauges of this type, together with Penning gauges and hot cathode ionization gauges, are now being used as pressure monitors in a vacuum system of a $1 \mathrm{Bev}$ electron synchrotron at the Institute for Nuclear Study, University of Tokyo.

\section{1. 序}

真空計の一種に thermal gauge がある。これは気体 の熱伝導率が、真空度がよくなるにしたがってだんだん 小さくなることを利用したものである。thermal gauge にもいろいろの種類があり、ピラニゲージなどはその代 表的なものであるが、サーミスターも、その電父抵抗が 温度によって大きく変わることから、やはり thermal gauge としての可能性が考えられるわけである $(1,2,4,6) 。$

\section{2. 動作原理}

気体の熱伝導率 $\kappa$ は、戦位体積当りの分子数 $N$ と分 子の平均自由行程 $\lambda$ とに比例し、 $\kappa=K N \lambda$ (1)

* 東京大学原子核研究所 (東京都北多摩郡田無町)
で表わされる。但し $K$ は分子の質量、気体の温度など によってきまる常数である。

気体の熱伝導率が真空度によって、どのように変化す るかを考えて見る。 $N$ は気体の圧力に比例し、入は気 体圧力に逆比例する。したがって 関係なく一定である。しかし圧力がだんだん下って、分 子の平均自由行程が真空装置の寸法よりも長くなると、 気体分子は、分子同志の衝突よりも真空槽の壁との衝突 の方が多くなり、それ以上真空度がよくなっても入は 一定不変となってしまう。一方 $N$ は、圧力に比例して 少くなるから、(1)式で表わされる 力範囲では、玨力と平行して変化するようになる。サー ミスターが使用できるのは、この領域である。

この熱伝導率 を知るかが問題である。サーミスター・ゲージでは、サ 一ミスターを測定しようとする圧力気体中に支えて、こ 


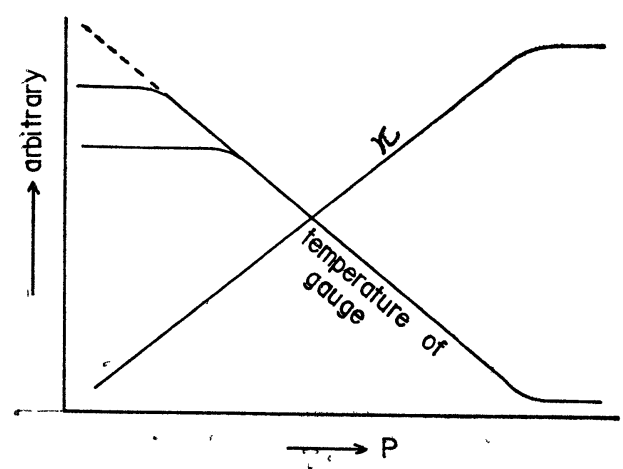

Fig. 1 Thermal conductivity and temperature of the thermistor gauge under constant power supply as a function of pressure.

れに外から一定の電力を供給しておき、そのときの温度 上昇 $\Delta T$ を検出するようになっている。この場合 $\Delta T$ は、

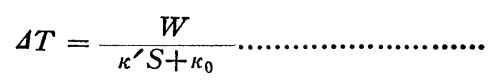

で表わされる。但し、

$\boldsymbol{\kappa}^{\prime}$ : サーミスターの単位面䅡から毎秒失われる熱量

$\left(\mathrm{Cal} / \mathrm{cm}^{2} \cdot \mathrm{sec}\right)$

$S:$ サーミスターの全表面積

$\kappa_{0}$ ：サーミスターを支えるリード線の熱伝導や輻射

などによって毎秒失う熱量 $(\mathrm{Cal} / \mathrm{sec})$

$W:$ サースターに入る電力

である。ここて述へる $\boldsymbol{k}^{\prime}$ は、(1)式で表わされる 比例する量てあり、 $\kappa^{\prime}$ の変化を $\Delta T$ の変化として読む ものである。

ここで $\kappa^{\prime}$ は前に説明したように、分子の平均自由行 程によって变化する量てあり、圧力と $\kappa^{\prime}$ との関係は

Fig. 1 亿示されるようなものである。一方 $\kappa_{0}$ はゲージ の幾何学的な寸法などによってきまるものであるが、こ れが小さい程低い圧力まて則ることができる。すなわち $\Delta T$ が $\kappa^{\prime}$ の变化て大きく变化するためには、

$$
\kappa^{\prime} S>\kappa_{0}
$$

であることが必要であり、更に

$$
\kappa^{\prime} S \ll \kappa_{0}
$$

の場合には $\kappa^{\prime}$ が変化しても、 $\Delta T$ は殆と変化せず、こ の場合のサーミスターゲーシは殆ど感度がないととにな る。一般に thermal gauge の使用限界は、高真空側て は、

$$
\kappa^{\prime} S=\kappa_{0}
$$

できまると考えられる。

そこて高真空側で則定範囲をのはすには、 $\kappa_{0}$ を小さ くすることおよび $S$ を大きくすることが考えら机る。

先ず $\kappa_{0}$ を小さするには、サーミスターを支えてい るリード線から熱伝䆃けよって失われる熱量を少くする

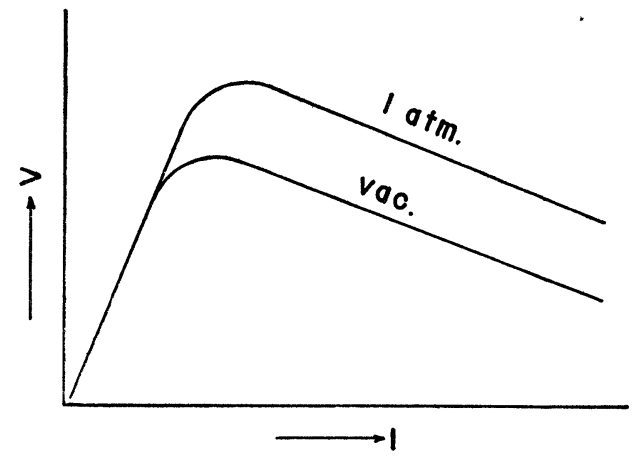

Fig. 2 Voltage drop across a thermistor (V) as a function of current ( I ).

ために、材料を選び、細いリード線を用いると同時に、 サーミスターの温度をあまり上けないようにする。これ は温度が高いと、輻射による熱の発散が無視できなくな るからである。

表面積 $S$ を增すには技術的な困難を伴うが、サーミ スターはなるへく薄い板状のものが望ましい。我々が用 いているものは、直径 $1 \mathrm{~mm}$ 厚さ $0.3 \mathrm{~mm}$ の板状の ものである。板状のものを用いるもう一つの利点は、サ 一ミスターの熱容量の割に表面積が大きいから、時定数 が小さくなり、応答時間も早くなることてある。

\section{3. 真空計としてのサーミスター}

サーミスターは、電気抵抗の温度係数が大きいから、 熱敏感素子として用いることが出来るのてあるが、その 電流電圧特性は、Fig.2 に示すように初めは直線的であ るが次第に直線より外れ、ある電统值に対して電圧は最 大となり、それ以上の電流に対しては電圧はだんだん減 少する。この特性は当然真空度によっても異なり、真空が よくなると同じ電流值に対する電圧は前よりも下がる。

このようなサーミスターに一定の電力を供給するのは 一般に簡単ではない。定電圧を加えた場合には、サーミ スターの温度上昇によって電気抵抗が减少して、さらに 電流が増し、遂にサーミスターが破壊してしまう。大き な抵抗を直列につないて電圧をかける場合には、との抵 抗がサーミスターの抵抗にくらへて十分大きければ、流 れる電流は殆んど一定とみてよく、サーミスターに供給 される電力は、サーミスターの電気抵抗によって変るこ とになる。

供給電力が一定の場合の圧力 $P$ と温度上昇 $\Delta T$ の関 係を考えると、分子の平均自由行程が装置の寸法て押え られる領域て注、(2)式において

$$
\kappa^{\prime} \propto P
$$

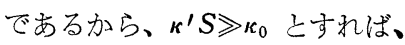




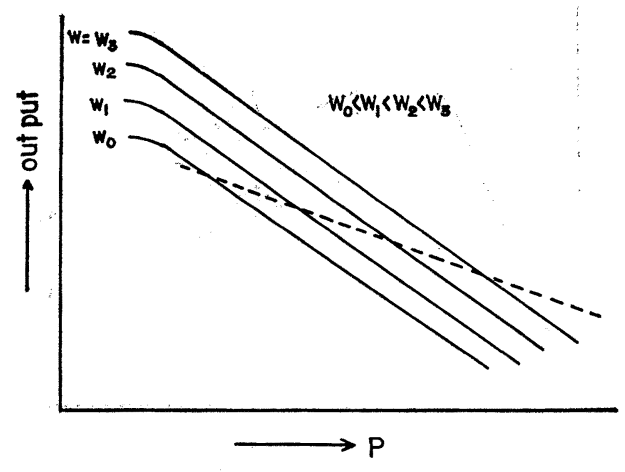

Fig. 3 Output voltage of the thermistor gauge as a function of pressure. solid line : constant wattage broken line : constant current

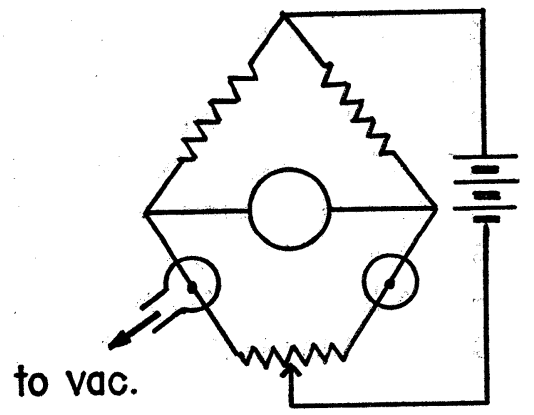

Fig. 4 A conventional circuit of a thermal vacnum gauge.

$$
\Delta T \propto P^{-1}
$$

となる。しかし、圧力が小さくなって $\kappa^{\prime} S \approx \kappa_{0}$ となると それ以上の圧力の变化には感じなくなってしまう。これ をグラフで表わすと、Fig.3に示すようになる。供給電力 を変えると、この曲線は上下に平行移動するだけで曲線 の形は変らないと考えられる。ところがサーミスターで 電流一定の場合には、温度の変化によって抵抗值が変わ り、供給電力が変るから、この曲線とは形が変ってく る。このときの曲線は点線で表わされている如く、もと の曲線より $\Delta T$ の変化は少い。このために、サーミス ターは温度係数怢大きいが、圧力に対する感度は若干減 少するのである。

\section{4. 室温による変動}

さてての温度上昇を如何にして検出するか。サーミス タ一の場合は、抵抗の変化によって $\Delta T$ を検出する。サ 一ミスターの両端の電圧降下を測るのである。しかして れだけでは、室温の変化に左右されて、真の $\Delta T$ は知 るととができない。補償用のサーミスターを一個加えて ブリッジを形成して、その電位差を読み取る方法をとっ

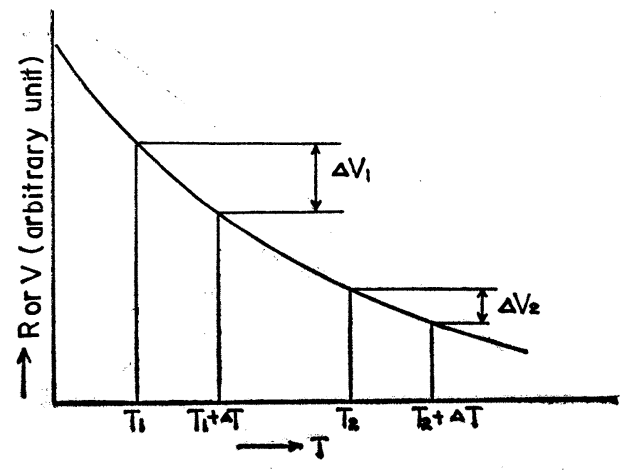

Fig. 5

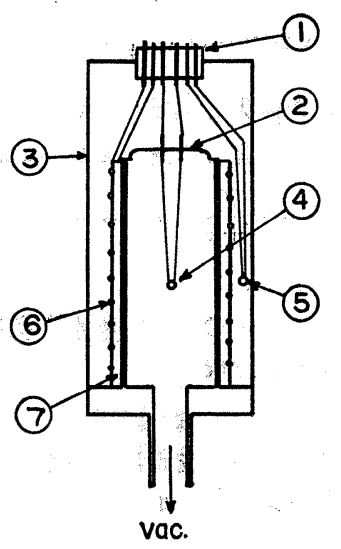

Fig. 6 Diagram of the thermistor gauge head.

(1). Cable connector (2). Kovar seal (3). Koyer.

(4). Thermistor for pressure measurement.

(5). Thermistor for temperature monitoring.

(6). Nichrome wire. (7). Bakelite bobine.

ても、サーミスターの温度と抵抗との関係が直線的でな いため、室温変化の影響をなくすととができない。すな わち Fig.5 に示すように二つのサーミスターの温度差 $\Delta T$ が同じでも、室温がそれぞれ $T_{1}, T_{2}$ であれば、 それにしたがって二つのサーミスターの電気抵抗の差 $\Delta R$ 注大きく変化してしまう。 $\Delta R$ 法出電圧に比例す る量上考えてよいから、出力は室温に大きく左右される ことになるのである。

\section{5. 室温の変化を逃げる方法}

この室温の変動による出力の変動を避けるにはどうす ればよいか。最も簡単な考え方は、ゲージへッドを一定 温度に制御するととである(3)(5)。その考えにしたがっ て、温度制御型のサーミスター・ゲージが作られ、温度 検出素子として、もう一つのサーミスターを用いること にした。サーミスターの温度係数が大きいから、このよ うな目的には都合がよい。ゲージヘッドには Fig.6 に示 寸ように、周囲に直径 $0.08 \mathrm{~mm}$ のニクローム線 のヒー 
ターが巻かれている。ヒーターの電気抵抗は約 $500 \Omega$ 位 である。これはあとで述べるようにもっと大きい方が望 ましいが、取扱上この程度が限度のようである。サーミ スターは真空部に一個、外側に一個ついており、外側の サーミスターで温度を検出して、その出力をファードバ ックしてヒーター電流を変えるようにしてある。また温 度の急激な変化を避けるためと保護のため、全体に力バ 一をから゙せてある。真空度検出用のサーミスターは、2 節でも述べた如く表面積の大きい方が望ましいので、こ こで用いたものは直径 $1 \mathrm{~mm}$, 厚さ $0.3 \mathrm{~mm}$ の板状の もので、 $20^{\circ} \mathrm{C}$ における電気抵抗が約 $5 \mathrm{k} \Omega$ である。温 度検出用のものは直径 $1 \mathrm{~mm}$ のビー玉状のもので、 $20^{\circ} \mathrm{C}$ 亿おける電気抵抗が約 $100 \mathrm{k} \Omega$ である。ヒーター の巻枠はベークライト製のものを用いた。動作温度は $40^{\circ} \mathrm{C}$ 以下であるから、乙れで充分である。

この温度検出用サーミスターによって、ヒーターを流 れる電流を制御してゲージへッドの温度を一定に保つの であるが、この温度の設定点を決めるに注次の考虑が必 要である。すなわち、温度はなるべく低い方がよい。温 度が高いと、熱輻射による損失が大きくなる他に、サー ミスターの抵抗も低くなって、出力電圧が小さくなるか らである。しかし、温度を制御するためには、常に室温 よりも高くなければならない。乙の結果、設定温度は $35^{\circ} \mathrm{C} \sim 40^{\circ} \mathrm{C}$ の程度とした。

温度制御回路は Fig. 7 江示寸ようなもので、ヒーター を流机る電流は、温度検出用サーミスターの両端電圧に よって制御され、サーミスターの温度が上り入力電圧が 下がるとヒーターを流れる電流法減少し、逆に温度が下 つて入力電圧が上がると、ヒーター電流が増すようにな つている。温度の設定点を变えるには、図の可变抵抗器 $\mathrm{VR}_{1}$ を変える。

こうして温度制御を行ったときのゲージーッドの温度 は、室温の約 $10^{\circ} \mathrm{C}$ の変化汇対しても $1^{\circ} \mathrm{C}$ 以内に押え ることができる。Fig. 9 亿示したものは、24時間運転 に拉けるゲージへッドの温度变化で、ととに温度制御 を行った場合と行わない場合とが示してある。温度の測 定はサーミスターで行った。

\section{6. 温度制御に関する考察}

このようなサーミスターを用いた恒温装置について、 室温の変動に対する温度の恋動率、およびスイッチを入 れてから定常状態に達するまでの時定数などについて考 えてみる。先ず、ゲージーッドについての温度変化に対 する少程式は次のようになる。

$$
C \frac{d T}{d t}+L\left(T-T_{0}\right)=W
$$

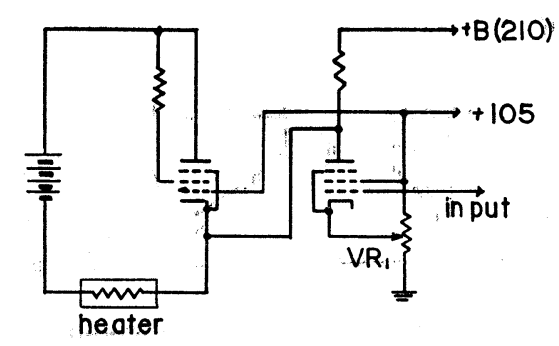

Fig. 7 Circuit diagram for temperature controle.

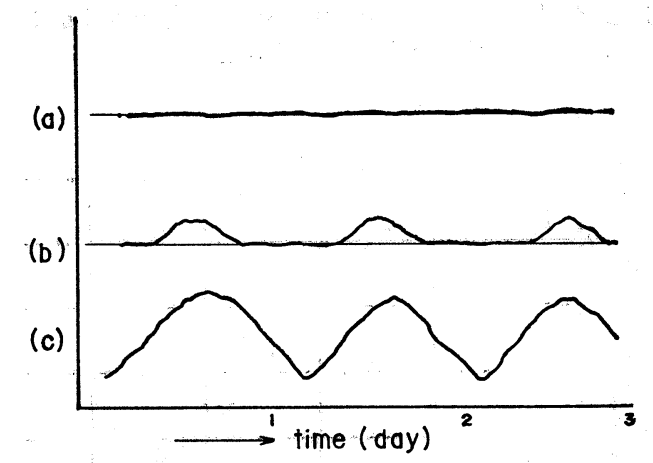

Fig. 8 Temperature change of the thermistor vacuum gauge head.
a) fully controled.
b) partially.
c) without controling.

但し、C はゲージへッドの熱容量, $L$ はゲージへッ ドからの熱発散の係数，W はダージーッドに毎秒加え られる熱量, $T_{0}$ は室温, $T$ はゲージヘッドの温度であ る。

温度制御を行うときは、 $W$ は $T$ によって変北するよ うにしてあり、 $T$ が上がれば $W$ は減少し、下がれば 増加するようになっている。てれを簡単に、

$$
W=W_{0}-A T
$$

の形で表わせるものとする。A は常数であり、増巾器の 利得や、温度検出朋サーミスターの感度などによってき まる。 $W_{0}$ は Fig. 7 に示した $\mathrm{VR}_{1}$ を変えるととによ って变わる常数で、これで温度の設定点がきまる。

(4)式を(3)式代入すると次のごとくなる。

$$
C \frac{d T}{d t}+L\left(T-T_{0}\right)=W_{0}-A T
$$

定常状態に打ける温度は、 $d T / d t=0$ として $T$ につ いて解いて求めることができ

$$
T=\frac{L T_{0}+W_{0}}{L+A}
$$

となる。室温 $T_{0}$ が $\Delta T_{0}$ だけ変化したときの $T$ の変 化を $\Delta T$ とすれば、

$$
\Delta T=\frac{L}{L+A} \Delta T_{0}
$$




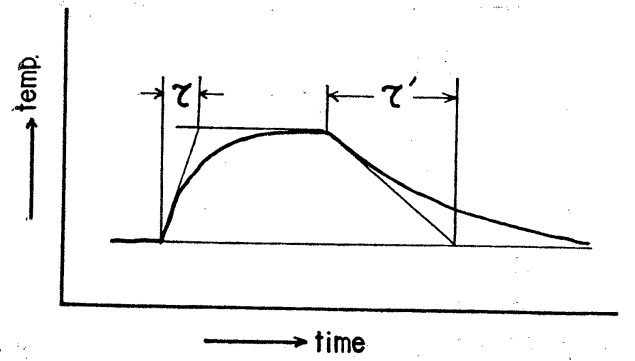

Fig. 9 Temperature change of the gauge head when the switch is on and off.

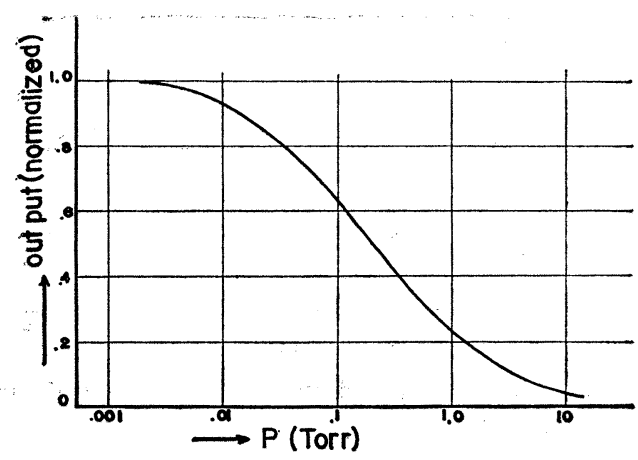

Fig. 10 Calibration curve of the thermistor vacuum gauge.

となる。温度制御回路の場合は $L \ll A$ あるあから（こ れは後述のように実際に確かめられた）

$$
\Delta T \risingdotseq \frac{L}{A} \Delta T_{\theta}
$$

となり、 $A$ が大きい程 $T$ の変化は少い。したがって増巾 器の利得は大きい程よく、グージヘッドのヒーターの抵 抗は真空管の内部抵抗と同程度でするととが望ましい。

つぎにスイッチを入れて動作を始めてから、常数状態 飞達するまでの時 定数については $\left(3^{\prime}\right)$ 式を $T$ につい て積分し、初期条件として $T(t=0)=T_{0}$ とすれば、

$$
T=T_{\infty}-\left(T_{\infty}-T_{0}\right) e^{-\frac{t}{\tau}}
$$

ただし

$$
\begin{aligned}
& \tau=\frac{C}{L+A} \approx \frac{C}{A} \\
& T_{\infty}=\frac{L T_{0}+W}{L+A}
\end{aligned}
$$

である。時定数は、Cが小さく $A$ が大きい程短い。 したがってゲージへッドの熱容量は小さい程よく、增巾 器の利得は大きい程よい。

$L$ と $A$ の比は実測によって推定することができる。
ゲージの電源のスイッチを入れると、(7)式で示されるよ うに温度が変化をする。その時定数は(8) 式で表わされ る。一方電源のスイッチを切ると、ゲージは自然冷却に によって除々に泠えて室温に達するが、てのときの温度 变化は(3)式で $W=0$ とおいて求めることができる。そ の結果時定数 $\tau^{\prime}$ は

$$
\tau^{\prime}=\frac{C}{L} \cdots \cdots \cdots \cdots \cdots \cdots \cdots \cdots \cdots \cdots \cdots \cdots \cdots \cdots \cdots \cdots
$$

であるとととは容易汇分る。この $\tau$ と和から $A$ と $L$ の比を求めることができて、つぎのような結果を得る。

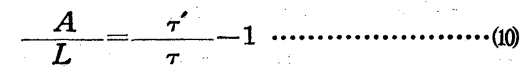

実測によれば $\tau, \tau^{\prime}$ はそれぞれ $\tau=3.1$ 分， $\tau^{\prime}=22.4$ 分であるから $A / L \risingdotseq 6.2$ であるととが推論される。

\section{7. 性 能}

サーミスターを用いた温度制御によって、実際にどの 程度の 温度变化があるかを Fig. 8 亿示す。(a) は温度の 設定点が適当な場合で、その温度変動は $1^{\circ} \mathrm{C}$ 以内に入 っている。(b)は設定点が低過ぎた場合で、室温が上って 来ると、温度制御が行われなくなる。(c)は全く温度制御 を行わない場合である。

真空度に対する較正曲線は Fig.10亿示す。圧力が 10 Torr 以下から 10-3 Torr までが 大体の測定範囲であ る。サーミスターを薄い板状にすると、もつと低い环力 迄測定できる筈であるが(2)(3)、技術的な困難が伴う。

核研電子シンクロトロンの真空系では、サーミスター ゲージで拡敢ポンプ系の背圧を測つてその信号をコント ロール系に送つている。またペニングゲージと組合わせ て、ペニングゲージの指度の二重性を識別できるように して高真空側の圧力を監視するようになっている。

最後にいろいろ御指導を賜わった熊谷教授、また多く の有益な御助言をして頂いた馬場斉氏に厚く感謝する。

\section{[交献]}

(1) P.E. Seiden : Rev.Sci.Instr. 28657 (1957)

(2) A. W.Smith : Rev. Sci.Instr. 30458 (1959)

(3) M. Varićak et.al. : Rev.Sci.Instr. 30 891(1959)

(4) A. P. Flanićk et. al. : Rev.Sci.Instr. 32356 (1961)

(5) A. R. Hamilton : Rev.Sci.Instr. 28 693(1957)

(6) J. H. Leck et.al. : Rev.Sci.Instr. 28119 (1957) 